\title{
Imitation in Children
}

\section{Miss Ellen M. Haskell}

To cite this article: Miss Ellen M. Haskell (1894) Imitation in Children, The Pedagogical Seminary, 3:1, 30-47, DOI: 10.1080/08919402.1894.10534795

To link to this article: http://dx.doi.org/10.1080/08919402.1894.10534795

册 Published online: 31 Aug 2012.

Submit your article to this journal $\pi$

Џll Article views: 15

Q View related articles $\sqsubset$

Citing articles: 1 View citing articles $\square$ 


\title{
IMITATION IN CHILDREN.'
}

\author{
By Miss Ellen M. Haskell, \\ State Normal 8chool, Worcester, Mavs.
}

From a great number of observations recorded by the students of the State Normal School at Worcester, Mass., in the study of children, nearly 500 have been selected which record imitative acts. A much larger number than this has been placed under two or three other rubries, which for the purposes of the psychologist should be classed with these. If, indeed, as seems possible, imitation is the mode in which all motor impulses discharge themselves, our entire collection might serve for illustrations of its operation.

It is perhaps necessary to explain that the recorders have made no attempt to do scientific work, - that would be wholly apart from the object in view, and, in the circumstances, impossible. Observing and recording is a part of the student's training for the occupation of teaching, because it awakens an intelligent interest in children. The records amassed are an incidental product remaining after the original and main purpose has been served. Whether they are the ashes of a furnace or a deposit containing precious metal, which will repay the labor of analysis and extraction, is for the promoters of science to determine.

The present writer believes that for the management and instruction of children, something is necessary which formal science, especially in the measure possible to be acquired without years of special study, has little power to impart. This something is intelligent interest, sympathetic curiosity, a feeling of charm in the tentative acts and the crudities, the failures and the make-shifts, the easily satisfied desires, the imperious demands and the unalloyed enjoyments of the infant man. There are many cases in evidence which show a growth of this curiosity, - this feeling of charm,-as the result of making and reading such observations as form the bulk of

The writer wishes to acknowledge her indebtedness for valuable aid and suggestions to $\mathrm{Mr}$. E. $\mathrm{H}$. Russell, Principal, Mr. T. L. Bolton of the State Normal School at Worcester, and Mr.J. H. Leuba, Fellow of Clark Univergity. 
this article, and it is for this reason that it has been judged best to print them with few comments and little attempt at arrangement. It is as unclassified instances of infantile acts and words that they have their greatest charm, and serve as the greatest stimulus to an ever up-springing interest and sympathy.

They have, moreover, a manifold character that makes classification extremely unsatisfactory. Each illustrates more than one quality or power, and hints at more than one explanation or law. They are almost as elusive and multiform as a child and have a strong tendency to make the reader panse, reflect, and perhaps finally suspend judgment, baffled, but delighted by a subtle feeling of knowledge and ignorance, kinship and strangeness.

That the imitative faculty is what makes the human being educable, that it is what has made progressive civilization possible, has always been known by philosophical educators. The energy of the child must pass from potentiality to actuality, and it does so by the path of imitation, because this path offers the least resistance or the greatest attraction, or perhaps because there is no other road. Whatever new and striking things he sees in the movements or condition of objects about him, provided he already has the experience necessary to apperceive this particular thing, he imitates. Helives under the influence of sensation, of emotion. "Every perception is a force pulling in a certain direction, and the child follows until he has grown enough in bulk and solidity to offer a resisting nucleus to impressions reaching him from without." But these truths must be re-discovered by each individual before they can become tributary to skill in child management. To put the reader on the road of re-discovery and application is the best ministry that remains for these records.

For the sake of form and clearness, these records of imitative acts have been separated into groups, not always easily distinguished from one another, but still each useful in illustrating a hypothesis or a truth. The first group presented is marked by an absence of the mental element, except in so far as mental action is involved in the immediate passage from the perception of a motion to the performance of it. The acts are reflex, most of them rhythmic movements. They mark no stage of growth, though they diminish in frequeney as age increases, and antagonistic sensations and inhibitive powers become stronger. All adults experience the impulses which give rise to such movements and yield to them more or less. 
"I watched F. and K. for ten minutes. (F. is a boy of three years, $K$. a girl of flfteen months.) $F$. sang, $K$. sang. F. danced, $K$. danced. $F$. stretched himself on the floor, $K$. did the same. $F$. laughed, $\mathbf{K}$. laughed. $F$, tied a handkerchief on his head, $K$. lound a piece of cloth and tied it on her head."

"The teacher of the infant class in Sunday school was teaching the children a song by rote. She stood before them and kept time with her head. The row of little heads before her bobbed in imitation."

"When Ella sang a motion song before the school, George went through the motions too."

"I saw a girl about six years old, standing near a railroad train, wave her hands while the conductor did so, and stop when he did."

"I stood before the baby (four months old) and whistled; she immediately puckered up her lips, but produced no sound."

"Gertrude (two years old) was sitting opposite me listening to the conversation. She made the same motions that I did, and when I put my hands on the table, she tried to do the same."

"This morning $\{$ walked to school with a boy four years old. It was raining and I told him he had better open his umbrella. He did it very willingly. It stopped raining and I told him he had better shut his umbrella. He said, 'I don't want to.' I then shut my umbrella and he did the same without saying a word."

"Ruth was angry and sat down in a chair and pouted. Margaret (twenty-three months old) sat down beside her and put out her lips as if pouting."

"I stood before the children in a first grade school and went through some gymnastic exercises, some of which were new, others familiar. I did not say a word, but the children imitated me and were quiet and attentive."

'Gertrude's sister hurt her hand, and ran to her mother to have it kissed. Gertrude (one year old) held up her hand in the same way."

"Philip was cutting with some dull scissors. He worked his mouth with the same motions that he made with the scissors. (Philip is twelve.)"

"I was beating an egg. Willie (eleven years old) rapped with a stick, keeping time with me. When told to be still he continued to make the motions of striking."

"When W. is corrected for wrong doing, she stops and looks sharply at the person correcting her. If he smiles, she smiles also; but if he looks severe, she cries."

"The school children (five, six and seven years) saw me laughing. They had no means of knowing why I laughed, but they all laughed."

Every adult can doubtless recall the exquisite pleasure he experienced in youth in impersonation. For most of us the pleasure is gone, because in part, perhaps, we are too keenly aware of the incompleteness and aw $\mathrm{k}$ wardness of our acting, in part because the constant necessity for self-control has produced a sense of shame at yielding to any free expression of feeling. We may thrill with emotion as we read Shakespeare, but nothing would tempt us to assume the postures, make the gestures that we see with the mind's eye, or speak in the tones that we hear better in solitude than in the theatre. 
The adult imagination needs, for most of us, to be stimulated by scenery, by costume, by circumstance, bat two-year-old Willie puts on his tather's belt, collar and cuffe, and taking a stick of wood in his hand, says, "See, mamma, I p'liceman; I's Mr. Matters !" Mabel, of the same age, dresses herself in a vest, cap, large slippers and spectacles, and on being asked who she is, makes the same reply. She happens to see herself in a looking-glass and dances and cries out for joy. She needs no audience for her drama and lets nobody into ber secret until she is asked. It is enough for her that she is that extraordinary and exceptional person that occa. sionally passes the house. She is not "making believe" in the sense these words have for older persons ; she is rather "in the state of a hypnotized person, to whom the suggestion of being some one else has been made." Her sensations are simple and unalloyed as those of mature people can rarely, if ever, be. Herbert, at three years old, sees an organ-grinder and monkey. Henceforth he needs only a fancy cap and the cover of a sewing machine to act what to him is the leading part in the drama he has seen. Not even an actor to take the inferior part is required. He sits on the machine cover and hears in imagination the tune played, then jumps down and, cap in hand, collects the imaginary cents. For him this is enough. His capacity for enjoyment is filled. He wants a cap and he places the "organ" on a lounge, evidently to have the sensation of jumping down from a height, as an aid to the illusion of being a monkey. D. took a slate under his arm and walked back and forth from one room to another crying Sunday Telegram. The record makes no mention of asking members of the family to buy papers. Perhaps he had never seen a paper sold; at any rate that was no part of what he had perceived, and was unnecessary to his idea of a paper boy.

A child, two years and three months old, went to the cellar door and called in different tones of voice. Whether this was a drama in which the child personater in turn the questioner and respondent, or whether the pleasure consisted in the sensation caused by the difference in tone, emphasized by the resonance from the cellar, cannot be known. That it was the latter is made probable by later reports of the same child. He is observed frequently to strike different objects, as a door and a chair, and to listen after each blow, as if noting the difference in sound. Children of four are, however, reported as acting dramas in which they take the part of three or four persons. Lulu, for instance, often plays "go to ride," and on the road asks and answers such questions as the father, mother and one or more children might ask and 
answer. Two voices are all she can command, however, and these are used in question and reply, respectively, rather than as belonging to the dramatis persona.

It is donbtful whether the following is an instance of personation or not. It is quite probable that in doing what the stone cutter did, Payson was no longer the child, but the strong man. "Payson is two years old. He often goes to a stone quarry, where he sees stones moved by a derrick. After hammering a block of wood for a time, he made a feint of lifting it and said :

" 'Want to lift it up.'

“" Well, lift it up,' sald his mother.

" 'Want to lift it up like a stone.'

" "Well lift it up like a stone.'

“"Want a derrick,' said Payson."

In his mind the atone was not to be "lifted," except by the use of a derrick.

How fluid the personality of children of this age is, and how readily they pass from one personation to another is well known. Bometimes a parent says: "My child is not the same person two minntes at a time." Not persons only are imitated, but whatever animals may have been seen or conceived from nursery tales. Most records of these impersona. tions, however, have the character of games and have boen placed in another class of observations, under the head of play.

By the time the child is six years old, there is an observable difference in the objects and acts imitated, but there is no time when we can say: "At this age, imitations have this character; up to this age, they had such another character." Of one child continuously observed, this might be true, but this would afford no sure ground for generalization, nor is it quite clear that it would yield any important educational results.

In the period between three and six, not attempting to be precise, however, most children add greatly to their experience by becoming in larger measure their own caretakers. They play with other children in the street, and with them, as well as with their parents and older brothers and sisters, make longer excursions and visit more places of interest. The intellect has also developed and makes more complex concepts possible. One feels slightly, too, that the discipline of repression has begun to work, that there is a slight loss of naïveté and a slight presence of self-coneciousness. The prison house begins already, if not to close upon the growing boy, to cast its shadow towards him. Something of motive or purpose may sometimes be discerned, perhaps, 
and a growing shyness which leads the actor to become him. self if he is observed, or to practice his dramas in secret. This is more marked later still.

"Harry is six. He went to a few of the Murphy (temperance) lectares. I saw him stand on the piazza and talk to a little boy that plays with him. He tossed his arms several times and I knew he was talking loud, but I could not hear him. I saw him a little later and asked him what he was playing. He said, 'I wasn't playing. I was Mr. Murphy then, and I have made Willie sign the pledge." "

This seems a great advance on the imitation of a policeman by the child of two and a half, yet the younger child, when asked what the policeman did, approached each member of the family and, shaking him, said, "Be dood." This last act was not spontaneous and did not form a necessary part of the idea, policeman, as the gestures, loud voice and signing the pledge did in Harry's case.

This is related of a child less than four :

"Willie went to an auction room with his father. The next day he held up an old jacket and said to the servant girl, "Take it, Lillie, for thirty cents. There it goes, for thirty cents."

"John stood in an empty freight car, turning the brakes round and round. Then he walked to the other end of $t$ he car, signalling with his arms, as brakemen do."

"Lawrence had a shawl strap buckled about his waist, and a poker thrust through it on one side. This, he said, was a sword. He marched round the house singing a medley of 'Yankee Doodle,' 'Marching through Georgia' and 'After the Ball."

"A long procession of ponies and dogs, led by a band of music had passed. In a few minutes Charlie went into the house and brought out a flag. He said to his companion, 'Follow me on your velocipede.' The leader marched, keeping time by stamping, and led his follower through many difficult turns. At times he waved the flag, but most of the time held it frmly against his side, as drilled men sometimes hold their guns."

"J. had been to the barber's and had his hair cut. Three or four weeks after, the long hair on the dog's head was found to have been cut off. J. admitted that he cut it because he wanted to be a barber."

"Bessie was found digging in the snow with her cloak unbuttoned and flying open. I said, 'Why don't you button up your cloak?' She answered, 'Don't you see I's working like a man, and mans has their coats unbuttoned." "

"Lizzie has a sister who is lame. Last night I saw Lizzie standing on one foot, holding in her hand the handle of an umbrella. The following dialogue was held:

$I$. "Lizzie, I would not stand on one foot.

L. " 'I have to.'

I. "No, you haven't. You'd better stand on both your feet and then you won't fall over.

$L$. " 'I would if somebody pushed me.'

I. "Well, nobody will push you. 
L. " 'I can't belp it, I'm lame.'

I. "O, no, you are not, are you?

L. "' 'Yes, I am. I have to use a stick like Mary's.'

I. 'I would not pretend that I was lame, for I wouldn't like to be leme.

L. "' 'Well, I am. See.'

"She walked along leaning on the cane and hopping up and down. I went my way, and Lizzie told her sister that I should always think she was lame because she made believe."

Greater experience and increased intellectual power are manifest in all these, and the sufficient reason remains the same for all: the agreeable sensation of abdicating one's own familiar personality and acting in the mental guise of another. In the last record quoted, there is a degree of sophistication unpleasant in so young a child. The "ways of the world" seem to have already roiled the limpid waters of the mountain brook of earlier childhood. Another record relates that four children with the equipment of a bunch of lilacs and a stick, marching like a procession with the seriousness that an elaborate regalia and pompous music beget, suddenly stopped on seeing a man whom they knew. What feeling overcame them can only be guessed, but some fear of acting freely and spontaneously had evidently entered in.

As children approach the tenth year the added experience and increased intellectual power become more apparent in the elaboration of imitative acts. The social element appears, and a need of accessories and properties. Three girls, who hold a funeral service for their dead cat, prepare a tombstone in advance, put on black dresses and veils belonging to their mothers, and, after an address by one of their number, sing, "Sister, thou wast mild and lovely." They are serious throughout, for the eldest is but nine years old. Two or three years later, when the sense of the ridiculous was further developed, the singing would doubtless have been interrupted by laughter Another group of three girls, the eldest nine, imitate the preaching of a minister by repeating in turn a form of words not very unlike what they have heard at church, but add that curious element of make-believe, the charm of which is perennial and all-pervading. They arrange their blocks like settees and place spools on them to represent the congregation. For consistency's sake, or for some other reason, they arrange a pulpit and place a spool in it for the preacher, and then, disturbed by no incongruity, themselves do the preaching. How far they fancied the voice to proceed from the spool-preacher, and how little his existence interfered with their own impersonation of the preacher, is not clear, but a highly interesting state of the child mind is dis- 
closed. While it requires a fitness of things up to a certain point, it contents itself with glaring omissions or mal-adjusted arrangements. The completeness which the adult mind demands, it is wholly indifferent to, $y^{t} t$ the parent is often surprised at the scorn with which a make-shift is rejected which he thinks far better than that which the child adopts.

This has a bearing upon so-ealled logical processes in teaching. A logical process forced upon a creature that acts by impnlses and leaps, that crosses rivers without bridges and gulfs without boats, yet is blind to plain paths, is the Chinese bandage on the foot. It means present pain and everlasting disability.

Processions attract attention, but the records in this group of observations deal chiefly with the conduct of the leader or the organizer :

"Willie enjoys being captain. He uses a stick for a baton and sings the hymns which he has heard the Salvation Army sing."

"H. and J. have cut out letters from pieces of cloth and sewed them on their jackets to indicate that they belong to the Salvation Army."

"Dexter's father is a minister. Dexter is not yet seven, yet he visits the neighbors to hold religious services. He often asks to have the piano played and one verse of a hymn sung; then taking his place a little apart, preaches. What he says can not be reported, because his speech is so imperfect that he can not be understood. One day he asked for a hat. A man's soft felt hat was offered him, which he refused. (His father wears a derby.) He was then offered a choice, and selected a woman's hat trimmed with artificial flowers. He placed this by his side when he began to preach."

On this day it seems as if a new necessity had arisen; the bat had become a necessary part of the impersonation.

After $\mathbf{E}$. had been to church, he was observed to take his younger sister into a room apart and preach a sermon. The sister served for congregation, but he recuired as additional aids to the illusion a table and book.

"Some telegraph poles lay beside the road. A boy was sitting on one end looking at the diameter and saying, 'Sixty-five inches and sixty-nine." "

"L. takes great delight in measuring various things. She often spends half an hour or more measuring chairs and tables with a tape measure. She writes the number of inches, but not the name of the article measured."

The acts of measuring and recording have attracted her, but they have no necessary relations or ends.

"George had a lot of figures on his slate, instead of the regular number work

$I$. 'What does this mean?'

$G$ "I was being book-keeper'

I Is your father a book-keper?' 
G. "No, my brother is." "

"Edgar embodies all the force of an electric car when he pughes a broomstick along the track and shouts, "Get out the way, the 'lectric car's coming!" "

"A boy was taking snow from a gutter with a hoe. Several younger children were looking on. The boy said, 'I'm a city man! I get two dollars and a half a day.;"

"Henry tied a handkerchief around his head and put several hen's feathers between it and his head."

The record gives only this, but one can not doubt that a picture of an Indian had enabled him to forget himself and for a moment live another kind of life. A reminiscence states that the writer, by taking the seat from a child's express wagon and kneeling in the wagon, became a circus girl driving a chariot. The illusion was created by her position; when she knelt, only the upper half of her person was visible. Another reminiscence states that the writer at nine years used to fancy herself a trapeze performer by swinging on a pole resting on the hooks of two large palleys in her father's barn. She had never been to a circus, but had seen pictures of trapeze performers.

Here is a piece of ready improvisation of a drama :

"An undertaker's wagon was passing along the street. Six small boys ran from the sidewalk and walked beside it, three on each side."

"Fanny, seven years old, takes the bowl of warm milk that has been given the dog, and getting down on her hands and knees drinks it by lapping."

One of the most charming reminiscences reads thus. The incident occurred when the writer was seven years old :

"I was climbing up 'the ledge' with my sister when I caught hold of a grape vine which hung over a dangerous mass of rocks and swung on it. Any one seeing me must have inferred that I was trying to 'show off', but in reality I was playing that I was a fairy' or Indian girl like Nokomis, whose story had been told me."

Reminiscences sometimes disclose the fact that the conduct of children is grossly misinterpreted by adults. The writer of the last quoted record relates that one summer day she went to a wood-lot on her father's farm to spend an hour in being a fairy. To aid her fancy she went without her dress, her neck and arms being thus uncovered. On her return she was seen by her father, who somewhat sternly ordered her into the house to put on her dress. His manner made her feel that she had behaved in a manner unbecoming a modest girl, and an hour of grief and shame followed her innocent and poetic enjoyment. The readiness to think evil of children arises in part, no doubt, from the great desire on the 
part of parents that their children shall be free from faults and vices, but also in part from a forgetfulness of their own youth. A bad motive is attributed to a child simply because in an adult a bad motive would underlie a similar act, when in truth the child is utterly incapable, intellectially, of the conceptions involved.

Any evidence of resthetic feeling is welcomed in children, but no class of feelings develops much in advance of other classes unless it is especially encouraged. The records afford little evidence one way or another on this point.

It is possible that æsthetic feeling may have furnished the impulse in the instances which follow, but it is not certain that they differ in this respect from other imitations :

"Grace came from her mother's bedroom with her face covered with toilet powder. Her mother said, 'Why, Gracie, what have you been doing?' Grace replied, 'Well, mamma, I guess I want to look pretty as well as you." Grace was four and a half years old.

"John (two years and four months old) arranged a row of colored cards on a box and then stood back from them while he looked at them. He called me to see them, saying, 'Pitty, pitty.' He had seen me do this same thing the day before.'

The following reminiscence is clear on this point. The writer was eight at the time :

"I kaw a picture of a girl lying down with her hands raised until they came at about a level with her shoulders. I thought this an exceedingly graceful attitude, and afterwards when $I$ was running I would raise my hands."

However possible it may be that a perception of beauty or grace furnishes the motor impulse to many acts, it is certain that it is not in early life an inhibitive power. Deformed persons and lower animals, and even repulsive acts and objects, are imitated. The following are related of children less than three years old :

"Elmer had a piece of wood in his mouth which he called a smoke. He had seen the hired man smoke a pipe and heard his mother scold about the smell."

"Last week Helen saw my mother take a sliver out of her hand with a needle. Yesterday, Helen found a pin and without saying anything went up to her and began to prick her hand with the pin."

"A man who had a eore hand was staying at our house. Gertrude twisted her handkerchief around her hand and walked up and down in the orchard."

"H. arranged strips of cardboard on the floor like a pen, stepped in, got down on his hands and knees and made a grunting noise."

"Grace was at a hospital for treatment of her spine. In the same ward was a helpless idiot, who made the most dreadful faces. Grace's mother observed when she visited the hospital that Grace made the same kind of faces, and I observed after Grace came home that her face sometimes took on a close resemblance to that of the idiot." 
It is probable that this was more reflex than voluntary.

The unusual appearance and conduct of the sick attract the attention of children and are imitated :

"My mother had the toothacho, and to ease the pain tied a piece of flannel around her head. T. and W. got small pieces of flannel warmed them at the stove, as they had seen my mother do, and held them up to their cheeks. Both made faces as if in pain."

"L.'s brother had a flannel band around his throat because be was hoarse. L. asked to have one around his throat and cried when it was refused him. At last, it was given him and he wore it to school.'

The desire in this case looks like the well-known desire for distinction which in later life is gratified by the assurance of a physician that our disease has peculiarities, or that we require a treatment or regimen different from that of other patients.

The same observer relates that after seeing a playmate with a pretty handkerchief tied on her head, she was seized with a strong desire to wear on her head a certain admired handkerchief of her mother's. Some excuse for wearing it was necessary, and she feigned an earache. Fsthetic feeling was the stimulus to this imitation.

"Mildred spent two or three days with her sick cousin. When she came home she filled a bottle with water and said, "This is medicine.' She rolled some bread into small balls and putting them into four boxes said, 'These are pills.' Before each meal she would say, 'I must go and take my medicine;' and eat one of the pills. One night she said, 'I don't feel very well, I guess I won't have any supper,' and taking sotne of the water from the medicine bottle lay down upon the lounge. When playing ont of doors she interrupted her play to go into the house and take a pill she would say, 'I don't feel very well, I must take a different kind of medicine from that I took last;' and get it from a different box This continued for more than a week."

The feeling which prompted these repeated acts at inter vals, through the long period of a week, must have been highly pleasurable. It is not related that the child asked for any sympathy or attention. She acted a part, day after day with no aid but the taking of make-believe medicine.

In these cases the children were between four and six. This age furnishes many instances of imitation of lame or deformed persons :

"Our hired man had a deformed foot and his shoes for that foot turned up at the toe after a few days' wearing. One night when my mother took off George's shoes, she noticed that the toe of one turned up slightly and on examination found strings, pieces of cloth and cotton in it. She asked George why they were there, and he said, 'Why, Stickney's foot turns up and I want mine to." After this my mother asw George on several occasions, when be did 
xot know that he was observed, take off his shoe and take great pains to make the toe stay bent. He would then watch for Stickney and follow him, imitating his halting gait."

To realize something of the change which years make in us, we have only to recall the varied and conflicting emotions which an adult experiences in observing any deformity; the shock to the resthetje feelings or the awakening of the sense of the ridiculous, pity, sympathy, contempt, aversion, pride, self-gratulation, and, surviving underneath all, the impulse to imitation, inhibited with shame or indulged with amusement.

"The music teacher has no left hand, and in keeping time beats with his right hand on the stump of his left arm. Yesterday, when the children were beating time, I noticed that two children pulled their left sleeves over their hands and beat on their arms."

These children were seven, but a boy of five is reported as doing a similar thing.

"A man with one hand had been calling on Dannie's parents. After he had left the room Dannie was seen with his sleeve pulled down so as to completely cover his left hand, while he worked industriously with his right.'

There are reports of boys carrying their arms in slings made of their handkerchiefs and pieces of string; of girls walking on improvised crutches, and walking in the street, apparently unaware of the presence of observers, with a halting and stooping gait. A young woman reports of herself that at the age of about five years she was envious of deformed persons. She remembers putting the bent end of the poker under the middle of her foot and holding the handle close to her hip, in order to walk as she had seen a man with a cork leg walk.

Another says : "When we played house I used to bend forward to appear humpbacked;" and still another states that she was so much given to walking with sticks under her arms for crutches, that her mother forbade it, only, however, to give it an additional fascination and cause it to be practiced in secret. She also walked with a limp, until her mother was afraid it would become a habit. There is probably no danger from such practices. The child is yet in too fluid a state to establish any bodily or mental habit, and new experiences and the necessity for change forbid the long continuance of any act.

The mental excitement attending a revolting act sometimes causes it to become a favorite pastime, as in the case of children of nine and twelve who had seen pigs killed. One was stretched on the floor while the other aimed a knife at her throat, and then imitated the process of ripping open the 
body. This was probably an entirely simple pleasure in the repetition of a strong emotion, and foreshadowed nothing whatever in the character of the growing girl.

A desire to do things because older persons do them appears early, and often exhibits itself in amusing and charming ways. In the first of the two following cases this appears to be the motive for the act, but in the second it is less clear. The motive may have been curiosity :

"Mary (a year and eight months old) has often seen her father smoke a cigar. She holds a toothpick between her lips and smacks her lips as her father does."

"Mary (one year and eleven months old) opened her baby brother's month and rubbed her finger along his gums as she had geen her mother do."

In the following cases, the ages are from two and a half to three :

"Payson had seen me swing Indian clubs. Some crook-necked squashes were brought into the house. Payson was seen to swing them about, apparently in imitation of me."

"Arthur takes a book and mumbles to himself, casting his eyes across the page as if reading."

"F. L.'s father had finished the newspaper and laid it on the table. F. L. took it up and pretended to read, saying, 'cat, rat,' etc., all the time holding the paper upside down."

"Every evening $N$. and $K$. do their examples for the next day. May also does her examples. Sometimes she has a pencil and paper, sometimes she sits still without talking."

"In the children's class to-day, Mildred, who is four, sat in Miss $R$.'s chair whenever Miss $R$. left the room. In the songs she turned towards the children, clapping her hands first to one, then to another, much as Miss $R$. would have done."

The following instances are arranged in the order of age. $J$. in the first record is three and a half ; the writer of the last was eleven at the time of the act. Progress is shown rather in the kind of thing desired than in any change of feeling. In all cases there is a simple reaching out for the condition of persons larger, stronger, more regarded, freer in their activities :

\footnotetext{
"J. was making marks with a pencil. He put the point in his mouth. Then he said to $\mathrm{K}$;; 'You must do that if you want to write; my grocery-man does it.', 'Y

"Ernest said, ' $\mathrm{T}$ wonld like to wear pants, and then I could have a pocket up here in my vest, and $I$ would keep a long pencil in it, and then I would turn back my coat like this (turning back his cloak) and take out my long pencils and use them; then I would stand them up in my pocket again and put back my coat.'"

"Mrs. - said to Phoebe's mother, 'I always take off my wrap in the cars, it makes me so uncomfortable.' Phobe took her doll's cloak off. Her mother said, 'What are you doing that for ?' 'My dollie can't bear to keep her wrap on in the cars."
} 
"I took a chair away from the stove, saying, "How the varnish smells!" Shortly afterwards Elsie pulled a chair away from the stove, saying, 'I smell the varnish!' She made two or three snuffs as she did so."

"I thought of an amusing incident and laughed to myself. Lulu said, 'What are you laughing at ?' 'My thoughts,' I replied. Soon after L. gave a forced laugh. I did not notice it until it was repeated. Then I said, 'What are you laughing at ?' and she replied, "My thoughts.'"

Girls from six to eleven are frequently observed holding up their dresses when they cross a street. One observer saw eleven instances of this during one morning.

"When I was about nine, hoopskirts were fashionable. Several of us school girls wanted to wear them. We each tore a hole in the hem of her dress and through this passed the long stems of the goldenrod, enough in number to reach round the skirt. We wore them in school."

"I used to visit a lady who had kept a doll that she had when a child. I thought I was too old to play with dolls, so I put one away in a box with all its clothes to keep till I was old enough to show it to children. I kept it in the box about two weeks, and I continued to play with dolls for about two years."

The educational value of a readiness to gain new experience is obvious. It shows itself early and continues in force until it is checked by self-consciousness, timidity, shame at failure, and prudence. It is the germ of the adventurer's spirit and develops into that when habits of industry and discrimination are not formed. It should undoubtedly be encouraged and the natural checks to it should not be applied too early. The following instances of this readiness are arranged, like the preceding, in the order of age. The first is the case of a child of nine months and the last of a child of nine years. A wider range might easily have been taken, but this serves the purpose.

"I have often sung to M. Now, when I begin to sing, she opens her mouth and appears to try to sing."

"Elizabeth has often seen Harlan open the slide in the stove door and put in pieces of paper to see them burn. To-day she has done the same thing, though it required much effort and painstaking."

"James was left alone for a short time. When his grandmother entered the room where he was, she found him standing on the table which he had reached by means of a chair. The door of the clock was open and the hands of the clock had been turned."

The following, made by an unusually careful and intelligent observer, might just as well be classed somewhere else, no doubt, but it is interesting as showing how the impulse to imitate, the desire for experience and, perhaps, the wish to be like an older playmate, work together to increase the child's power of uttering words and forming sentences: 
"J. repeats in some form certain words and sentences which he hears. His playmate talks a great deal; as, when going to run, he says, 'One to begin, two to show, three to make ready, and four to go.' J. attempted every part of this, though not a word was distinct. His sentence occupied the same time and was exactly like his playmate's in force. He imitated the vowel sounds where they were prominent. He repeats a statement as soon as it is made. Ordinary conversation is not repeated so much as orders or calls in any unusual pitch."

"Carpenters have been at work for three days on a neighboring house. J. spends much of his time carrying nails and a stone which he uses for a hammer from one place to another. Yesterday he drove two large nails into the doorstep."

"Willie saw his father put two of his fingers into his mouth and whistle. Soon after Willie was seen with two fingers in his mouth making a prolonged sound of oo. He said he was whistling."

"Winifred heard her brother learning poetry. She asked me to teach her some verses, and I did so. Later I heard her teaching her brother. She repeated a line at a time, telling him to say it after her. She held the book in her hand and pretended to read the words."

"At a festival, when the food was passed around by a waiter, several persons in the group where $S$. sat refused cheese by shaking the head. It was not offered to $S$., and he called out to the waiter, "Pass it to me so I can shake my head!'"

" Ethel asked to call on Mrs. A. When her ring was answered she said, 'Is this Mrs. A.? I am Ethel-Mrs. W.'s little sister. I have come to call on you.'"

" $K$. had read the rhyme about Bob who staid out of doors in the rain. She went out in the rain and personated Bob, who is said to have been borne along with his hat flying before him."

"Gertie was cutting from a newspaper a picture of a pair of scissors. She said to me, 'I am going to send this to New York to get some truly ones, 'cause when you send these to New York they send you back the kind to use." "

A sense of fun, a love of joking, is apparent in a few records :

"G. saw his tather catch a mouse the other day. Several times a day he goes under the table, puts his hand down on the carpet, gets up, goes to the door and pretends to throw something out. He then laughs and says, "Baby trow de mouse out.'"

"When I was four or five years old I used to imitate my mother's voice and then call my sister for the sake of fooling her."

"Alice asked me a question which I did not understand. I said, 'What did you remark?' She looked at me curiously, but said nothing. About an hour afterwards I asked her a question, at which she laughed and said, "What did you merark? what did you merark ?"

"We children used to repeat the conversation which our father and mother carried on in the Irish language. Some of the expressions were diffeult to pronounce, and this made us laugh so heartily that we were ordered to play something else. It was so amusing to us that we smothered our laughter with our handkerchiefs and aprons, that we might be allowed to continue it." 
It is not uncommon for a child to imitate a sound or an act when he is otherwise unable to express his thought:

"When A. sees a burning match he asks if he can 'fur' it out. The word 'fur' sounds like the noise he makes when he blows it out."

"Harlan was afraid his little sister would touch his clay spheres and cylinders while he was at the other side of the room. He said to me, "You keep saying "no, no, no," to the baby till I come back."

"When Willie saw me after his first day at school, he gaid, 'We have to do awful hard things at school. The teacher has a whole pile of shells and marbles and she makes us say "two shells and two shells," and we have to stand like this.' He then stood up straight with his feet at right angles, imitating the 'position' of the physical exercise."

"In the reading class was the sentence, 'The hen laid an egg.' Fannie stood up and said, "Teacher, our cow laid a little cow and he walks awful funny.' Then she got down on the floor and showed the way the little calf ran about."

"I hid a pencil which $O$. wanted, and when he did not find it he said, 'All gone!' swaying his right hand from left to right three times very gracefully."

In the following cases, which are evidently voluntary imitations, there is this in common with reflex acts, - there is no regard to the object or result of the act. Thus in the first case, Mary does not want the thread, but only to perform the unusual act of drawing it from the spool on the machine. In the second, Mabel does not care for the sound of the tuningfork ; she enjoys the movements of using it, or more likely is acting a drama :

"Katie, wanting some thread, pulled it from a spool that was on the sewing-machine. In a few minutes Mary did the same thing."

"Mabel had seen me use a tuning-fork. I have noticed her striking the table with a pencil, clothes-pin, or her finger, and then putting it to her ear to get the sound and trying to sing do."

"B.'s mother dips the comb in the wash-basin when she combs B.'s hair. If $B$. Is given a comb she strikes it on the edge of the basin before putting it to her head."

"I have been told that when I was sixteen months old I used to try to comb my hair, and always stood where my mother stood to comb hers, although the mirror was so high that I could not see into it at all."

"Katie saw her aunt dropping eye-water into her eyes through a quill. A few days later Katie was seen standing before the glass with a lead pencil stuck in her eye, and pretending she had a bottle in her hand."

"M. likes to sew. She asks for a needle and thread, but does not want the thread knotted. She will sit near a person sewing for a long time, drawing the thread through the cloth, seeming quite content, though she makes no stitches."

"Helen received a tub, washboard and clothes-horse at Christmas. Every day for more than a week she has gone through the motions of washing, using no water. She hangs out the clothes, which consist of a handkerchief, three or four worn kid gloves and a few doll's things. She irons them with a cold flat-iron and hangs them on the clothes-horse." 
These children were less than three years old, except the last, who was just three. The following are similar acts of older children, the oldest being eight :

"I made a noise by holding a piece of grass between my hands and blowing on it. Frank heard me and immediately picked a piece of grass and went through the same motions, but could not make a sound. He seemed contented and walked about on the grass for five or ten minutes, going through with the motions all the time."

"'Will you sing for me, Minnie?' 'Yes, in a minute.' She struck her finger on the back of a chair, held it up to her ear and hummed. This was not the right pitch; she struck her finger again. This time she was satisfied and began to sing."

"J. took a clothes-brush and rubbed it on the wall. He said he was papering."

"When Ida's mother and sister wish to say something not intended for Ida's ears, they spell the words. Ida precedes her sentences by a few letters she happens to know. I heard her say, ' $b$ o-s, mamma, tell Mamie to give me more candy." "

"The teacher has a spindle on her desk to keep papers or notes on. J. keeps a pin point uppermost on the ontside of her desk and sticks on it little squares of waste paper."

These records might all perhaps be placed in some other class, but they, nevertheless, illustrate the characteristic mentioned. A few more will be added, chiefly because they are interesting:

"A. is fifteen months old. When he is placed upon a pillow on the floor, he gets off the pillow, takes his foot in his hand and puts it on the pillow. He then covers it up and hushes it to sleep, as his mother does him."

"Last evening I watched Gertie, who is nine years old, making examples in arithmetic. This is one of them: 'If a man had a tree with sixty apples on it, how much would there be on a tree with fifty apples? "The answer was \$10."

"This is another: "A man had a tarm with fifty ear. If he sold them at $\$ 5$ a ears, how much? Ans. \$255.'"

"I was helping a little girl in the children's class to put on her cloak. She said, 'Say, what do you suppose Santa Claus is going to bring me?' Before I had time to answer she went on, 'Well, he's going to bring me a pony pump.' A little girl standing beside us said, 'He brings Sunday dishes and every-day dishes.' 'Yes,' said the first girl, 'and he's going to bring me Sunday dishes and everyday dishes.' 'Yes' said the second, 'and he's going to bring Mr. B. (the principal of the school) a set of Sunday dishes and every-day dishes." "

During the reading and arrangement of these observations the writer has been impressed with the necessity of giving more freedom to the promptings of instinct in children, of permitting them to take their own methods of doing and acquiring. The spontaneous activities of children are educative of the mind as well as imperative to the body, and yield not only experience,-universally admitted to be the best 
teacher, - but the invaluable power of self-help and selfreliance. In Mr. Ruskin's summary of the blessings and evils of his early training, he laments as the chief evil that his powers of independent action (not thought) were left entirely undeveloped, because the bridle and blinkers were never taken off. "Children," he says, "should have their times of being off duty, like soldiers; and when once the obedience, if required, is certain, the little creature should be very early put for periods of practice in complete command of itself; set on the barebacked horse of its own will and left to break it by its own strength."

Children are so ignorant of harm and so little able to protect themselves that few adults can restrain their fear of coming evil or stifle their desire to extend protection sufficiently to give the child even a measurable degree of the freedom he requires. Besides this, is the additional difficulty that so many of the child's activities are mischievous in their effects that it is almost impossible to avoid a habit of constant watchfulness, and an attitude of restraint. A child who has seen a house painter at work sees no harm in dipping a clothes-brush in water and rubbing it on a papered wall ; nor, when he has seen bread placed in the oven, in putting his shoe in the same place. Still, freedom is my plea. Not half so many bodily dangers beset the child as we fear, not half so many of his imitations are mischievous as we think; while the courage to attempt new things, the discrimination between what can be done and what can not, are qualities so valuable that much may be risked in their behalf. Moreover, the child is not only ignorant of the results of his acts, he performs them, as we have seen, without any reference to objective consequences. In seeking simply to enjoy a sensation, and acting without the checks which knowledge, reflection and altruism make operative with the adult, he is developing a personal power, growing as an individual, and gaining solidity and stability. He must live for himself until he gains a power of resistance and intelligent choice.

For the child in school a still stronger plea is needed, for here custom and tradition have piled up obstacles to freedom to an almost insurmountable height. The teacher who will take advantage of the instinct of imitation, as an artisan takes advantage of the fluidity of water, or the hardness of iron to effect his purpose, must create an atmosphere of freedom, in which the instinct can have free play. Repression, prohibition and compulsion must have the smallest place, and encouragement, permission and liberty to choose must prevail. 